\title{
Corruption and Growth in the Economic and Monetary Community of Central Africa (EMCCA): The Role of Democracy
}

\author{
Antoine Ngakosso, Fernand Owonda \\ Marien Ngouabi University, Brazzaville, Congo \\ Email: a.ngakosso@umng.cg, owondafernand@yahoo.fr
}

How to cite this paper: Ngakosso, A., \& Owonda, F. (2021). Corruption and Growth in the Economic and Monetary Community of Central Africa (EMCCA): The Role of Democracy. Theoretical Economics Letters, 11, 858-870.

https://doi.org/10.4236/tel.2021.114054

Received: July 9, 2021

Accepted: August 28, 2021

Published: August 31, 2021

Copyright (c) 2021 by author(s) and Scientific Research Publishing Inc. This work is licensed under the Creative Commons Attribution International License (CC BY 4.0). http://creativecommons.org/licenses/by/4.0/

\begin{abstract}
The objective of this paper is to analyze the role of democracy in the relationship between corruption and economic growth in EMCCA member countries over the period 2002-2020. The results obtained from this study, using the dynamic panel of the generalized method of moments (GMM), confirm the "grain of sand in the economy's wheels" hypothesis in the EMCCA countries. Furthermore, taking into account the interactive influence of democracy in the corruption-growth relationship reveals that democracy could reduce the negative effects of corruption on economic growth. The results of the study suggest that the promotion of democratic norms is crucial to limiting the level of corruption and stimulating economic growth in the EMCCA sub-region.
\end{abstract}

\section{Keywords}

Corruption, Democracy, Economic Growth, Generalized Method of Moments

\section{Introduction}

After several years of economic research, economic growth issues remain at the heart of economic and institutional concerns. According to the United Nations report (2021), the world economy recorded a contraction of $3.5 \%$ in 2020 , the largest decline since the great recession of 2009. This global reality has not spared the EMCCA countries, with average growth rates of $2 \%$ in 2019, compared with $-2.9 \%$ in 2020, (IMF, 2021). This being the case, the identification of factors likely to promote or slow down growth remains the main focus of studies on growth. If for Solow (1956) growth comes from the accumulation of the capital stock, the quantity of labor and technical progress, Lucas (1988) and Barro 
(1990) believe that it emanates from human capital and public capital. However, special attention is beginning to be paid to institutional issues, including corruption $^{1}$ and democracy ${ }^{2}$, which appear to be major variables in explaining differences between countries in terms of economic growth (North, 1990; Mauro, 1998).

Theoretically, the relationship between corruption and economic growth divides economists into two approaches: optimists and pessimists. Optimists see corruption as "oil in the bureaucracy's wheels" and improves economic growth in countries with weak institutions (Leff, 1964; Leys, 1965; Huntington, 1968); while pessimists (Kaufmann \& Wei, 1999; Seka, 2013) see corruption as a barrier to growth, i.e., corruption is a "grain of sand in the economy's wheels".

However, these two approaches find empirical support in several works, on the one hand Aidt et al. (2008) suggest that the effect of corruption on growth is conditioned by the type of governance. In regimes characterized by good quality institutional, corruption has a significant and negative impact on growth. In contrast, in political and economic regimes with low quality institutional, growth is not affected by corruption. On the other hand, Shera et al. (2014) analyzed the effects of corruption on economic growth in a panel of developing countries for the period 2001-2012. The results, obtained from a fixed-effects model, reveal that there is a statistically significant negative relationship between corruption and economic growth.

A few empirical studies on the relationship between corruption and growth in EMCCA have not taken into account the role of the political system to which the economies are subject (Ondo, 2017). The interest of this study is to revisit the corruption-growth relationship by incorporating the interactive issue of the type of democratic regime (Cooper Drury et al., 2006; Amira, 2014). This paper aims to capture the role of democracy in the corruption-growth relationship over the period from 2002 to 2020 and defends the grain-of-sand hypothesis.

In addition to the introduction and conclusion, the rest of this paper is structured as follows: point II, the literature review, point III, the methodology and finally point IV, the results and interpretations.

\section{Review of the Literature}

This section includes both theoretical and empirical reviews.

\subsection{Theoretical Review}

The theoretical literature is based on the "oil in the wheels" and "sand in the wheels" approaches to economic growth.

${ }^{1}$ Corruption is an abuse of public office that violates formal and informal norms, which directly or indirectly brings a gain to a public official who provides a third party with services or resources that would otherwise be more difficult or impossible to obtain. The examples all involve not only the behavior of public officials, but also "private employees" and independent agents LaFree and Morris (2004).

${ }^{2}$ Democracy acts as a counterweight to corruption-related behavior. It has both political and economic benefits (Wittman, 1989; Przeworski \& Limongi, 1993; Saha et al., 2014). 


\subsubsection{The "Oil in the Wheels" Approach}

Until the early 1990s, several authors presented corruption as an effective way to bypass regulations or slow bureaucratic procedures, thus enabling economic development (Leff, 1964; Huntington, 1968).

Indeed, corruption has long been presented as a means of compensating for the deficient functioning of public institutions. Leff (1964) and Huntington (1968) argue that corruption promotes economic efficiency by overcoming the rigidities imposed by governments. According to these authors, corruption would generally facilitate economic life by "oiling the wheels". This idea was later taken up and developed by Bardhan (1997) and many theoretical works show that corruption is a vector of efficiency.

Beck and Maher (1986) show, in the context of government contract allocation that awarding a contract to the firm that offers the largest bribe leads to the selection of the most efficient firm. Indeed, they show that in an imperfect information game, the firm with the lowest costs can offer the highest bribe.

On the other hand, the positive effects of corruption on economic growth in environments marked by inefficient public action have been refuted by Méon and Sekkat (2005).

\subsubsection{The "Grain of Sand in the Wheels" Approach}

Regarding the second approach "grain of sand", according to Bardhan (1997), public officials may deliberately create slowness and red tape in order to collect bribes. Kaufman and Wei (2000) corroborate this theoretical conjecture.

Schleifer and Vishny (1993) show that the ability of public officials to speed up an administrative procedure may be very low. This fundamentally challenges the idea that bribing is sufficient to speed up procedures or overcome administrative obstacles.

Furthermore, Méon and Sekkat (2005) show that corruption acts as a "grain of sand" in the gears of economic growth. Indeed, they point out that the effects of corruption depend on other aspects of governance (regulatory burden, rule of law, government effectiveness, etc.) and that the weaker the quality of governance, the more detrimental they are. In the same vein, two other views underlying the "oil in the wheels" approach are seriously challenged. First, the argument that corruption can help improve the choice of good decisions is strongly challenged by Rose-Ackerman (1997). Indeed, in his contribution, the private agents who pay the highest bribes are not always the most efficient. Second, the positive effect of corruption on the quality of public servants at the aggregate level is strongly disputed. For example, Kurer (1993) shows that corrupt officials have incentives to distort the economy to secure their illegal source of income.

The second set of works, mainly empirical in nature, challenges the idea that corruption improves investment and economic growth. According to the "oil in the wheels" approach, corruption can improve both the quality and quantity of investment. However, this does not seem to be true for public investment, for 
example. Tanzi and Davoodi (2002) show that higher corruption is associated with higher but inefficient public investment. They argue that this results from the diversion of public expenditure to less efficient uses. In other words, corruption results from more public investment in unproductive sectors.

\subsection{The Empirical Review}

Few studies have addressed the question of the nature of the political regime (democracy versus autocracy) and its role in the corruption-growth relationship. Conventional wisdom articulates that corruption is lower in democratic regimes where checks and balances are more prevalent, but there is no conclusive empirical evidence of a trilogy relationship between these three variables. Cooper Drury et al. (2006) show, following a dynamic analysis of a cross-sectional time series data set of 100 countries over the period 1982 to 1997, that democracy moderates the harm of corruption on growth through elections. As a result, only non-corrupt politicians should be re-elected. The authors conclude that corruption has no effect on economic growth in democratic countries. Nevertheless, it has a significant and negative impact in non-democracies. Similarly, Amira (2014), using a dynamic approach (GMM) of panel data for more than 40 countries over the period 2000-2011, found that in democratic countries corruption has no significant effect on growth, while non-democratic countries are negatively impacted by corruption and retard economic growth. Furthermore Ghulam (2017) indicates that democracy plays a key role in determining the corruption-growth relationship, and suggests the promotion of democratic norms very essential in limiting the level of corruption and stimulates the economic performance of the nation.

Two major lessons emerge from this empirical review: first, the relationship between corruption and growth is conditioned by the type of political regime. This being the case, corruption can only have negative effects on growth in countries with low levels of democracy. On the other hand, in countries with a high level of democracy, corruption does not have significant effects on growth. This is what we will verify in the case of the EMCCA countries.

Second, it is apparent that all studies addressing the question of the role of democracy in the relationship between corruption and economic growth have relied on a dynamic method called the generalized method of moments. Thus, for this paper we make use of the same method as did Cooper Drury et al. (2006) and Ghulam (2017).

\section{Methodology}

\subsection{Model Specification}

We start from the idea that corruption is one of the negative determinants of growth. It is seen as a barrier to this measure of wealth. This is consistent with the literature (Mauro, 1995). On the other hand, democracy is likely to reduce 
corruption and thus stimulate growth. The estimates in this research first address the corruption-growth relationship. Second, we insert the democracy variable into the model as a control variable, in order to analyze simultaneously the effect of democracy and corruption on growth.

Third, the question of the interactive influence of democracy in the corruption-growth relationship. This relationship can be verified by the sign and significance of the interactive coefficient between democracy and corruption, as done by Cooper Drury et al. (2006). If this coefficient is positive and significant, democracy reduces corruption and therefore stimulates growth. Drawing on the study by Cooper Drury et al. (2006) which used the dynamic panel of generalized method of the moments (GMM), our models are as follows:

$$
\begin{aligned}
& L P I B_{i t}=\alpha l_{p i b} b_{i t-1}+\beta X_{i t}+\gamma(\text { Corr })_{i t}+\mu_{i t}+\varepsilon_{i t} \\
& \operatorname{LPIB}_{i t}=\alpha \operatorname{lpib}_{i t-1}+\beta X_{i t}+\gamma(\text { Corr })_{i t}+\delta(\text { Demo })_{i t}+\mu_{i t}+\theta_{i t}+\varepsilon_{i t} \\
& L P I B_{i t}=\alpha \text { lpib }_{i t-1}+\beta X_{i t}+\gamma(\text { Corr })_{i t}+\delta(\text { Demo })_{i t} \\
& +\delta^{\prime}\left[(\text { Demo })_{i t} * \text { corr }_{i t}\right]+\mu_{i t}+\theta_{i t}+\varepsilon_{i t}
\end{aligned}
$$

With $L P I B_{i t}$ the logarithm of the GDP growth rate of year $t$. the variable $(\text { corr })_{i t}$ represents the direct effect of corruption on growth. Similarly, the variable $(\text { demo })_{i t}$ represents the effect of the latter on growth, while the variable $\left[(\text { demo })_{i t^{*}}(\text { corr })_{i t}\right]$ represents the interactive variable between democracy and corruption, $X$ is the matrix of control variables, $(\alpha, \beta, \gamma, \delta)$ are coefficients to be estimated, and then, $\mu, \theta$ represent respectively the individual specific effects, the temporal specific effects and finally $\varepsilon$ the error term.

\subsection{Data and Variable Definitions}

This study mobilized two types of data of macroeconomic and institutional na-

\begin{tabular}{|c|c|c|}
\hline Variables & Definition & Sources \\
\hline \multicolumn{3}{|c|}{ Macroeconomic } \\
\hline LPIB & the logarithm of the annual growth rate of GDP & $\begin{array}{c}\text { World Bank } \\
\text { database, } 2020\end{array}$ \\
\hline Lpop & the logarithm of the rate of population & $\begin{array}{c}\text { World Bank } \\
\text { database, } 2020\end{array}$ \\
\hline LFBCF & $\begin{array}{l}\text { the logarithm of gross fixed capital formation as a percentage of } \\
\text { GDP }\end{array}$ & $\begin{array}{c}\text { World Bank } \\
\text { database, } 2020\end{array}$ \\
\hline
\end{tabular}
ture. The economic variables are exclusively from the World Bank database (WDI, 2020), and the institutional variables are extracted from (WDI, 2020) and Freedom House ${ }^{3}$ (2020).

${ }^{3}$ Freedom House is an independent watchdog organization dedicated to the expansion of freedom and democracy around the world. Freedom House analyze the challenges to freedom, advocate for greater political rights and civil liberties, and support frontline activists to defend human rights and promote democratic change. Founded in 1941, Freedom House was the first American organization to champion the advancement of freedom globally. 


\section{Continued}

\begin{tabular}{|c|c|c|}
\hline LDP & $\begin{array}{l}\text { the share of public expenditure allocated et each expenditure } \\
\text { sector taken in logarithm: education, health, social protection, } \\
\text { defense, public order and services, housing, culture, energy and } \\
\text { fuel, other economic activities }\end{array}$ & $\begin{array}{l}\text { World Bank } \\
\text { database, } 2020\end{array}$ \\
\hline \multirow[t]{2}{*}{ FDI } & the nets flows of direct investment & $\begin{array}{c}\text { World Bank } \\
\text { database, } 2020\end{array}$ \\
\hline & Institutional & \\
\hline
\end{tabular}

Index of democracy: consider two components of freedom. The Political Rights Index measures the extent of free and fair elections, political pluralism, and political minority rights. The Civil Liberties Index measures civil liberties and individual freedoms such as freedom of speech, freedom to practice one's religion, and freedom to assemble peacefully. Both indices range from one to seven, where lower numbers indicate higher levels of freedom. To determine the Demo variable, we take the

Demo average of these two indices. Countries are coded from 1 to 7 in terms of political rights and civil liberties. While " 1 " represents the most democratic country (advanced democracies), " 7 " means the least democratic country (unfree, lack of democratic principles). In addition, countries with an average of political rights and civil liberties between 1.0 and 2.5 are classified as "free countries"; countries with an average between 3.0 and 5.0 are defined as "partly democratic" and countries with an average between 5.5 and 7.0 are "not free countries"

the control of corruption in country (i) at time (t) (CC): this indicator measures the use of the prerogatives of power for personal gain, in particular the enrichment of individuals in CC positions of power. Developed by Kaufmann, Kraay and Mastruzzi (2010). It is evaluated according to a range that varies between -2.5 and 2.5. A value below the average of 1.25 reflects endemic corruption. While a value close to or above the average of 2.5 (WDI, 2020). reflects low corruption

Demo*Corr. the variable that captures the interactive influence of democracy

\subsection{Generalized Method of the Moments (GMM)}

The method of Arellano and Bond (1998) provides a more efficient "GMM" estimator, allowing to check the absence of first and second order autocorrelation without taking into account heterogeneity. The GMM estimator in first differences has some shortcomings, since level lagged variables are not good instruments for first differences variables. Arellano and Bover (1995) and Blundell and Bond (1998) proposed an alternative GMM estimator in system based on the initial conditions and taking into account the moment conditions, in order to combine the first difference equations with the level equations and the first difference variables as instruments.

$$
\begin{aligned}
\Delta Y_{i t} & =\beta \Delta Y_{i t-1}+\varphi X_{i t}+\Delta \vartheta_{i t}+\varepsilon_{i t} \\
Y_{i t} & =\beta Y_{i t-1}+\varphi X_{i t}+\Delta \vartheta_{i t}+\varepsilon_{i t}
\end{aligned}
$$

The main tests associated with these estimators in dynamic panels are: the 
Sargan/Hansen over-identification test, which allows us to test the validity of lagged variable as instruments.

\section{Results and Interpretations}

Before we present the results of GMM test and in accordance with the work of Holtz-Eakin et al (1990), Arellano \& Bond (1991) and Arellano \& Bover (1995), a macroeconomic panel is conducted as a time-series study. Therefore, we first present the stationarity and cointegration tests. The results are presented in $\mathrm{Ta}$ ble $\mathrm{A} 1$ and Table $\mathrm{A} 2$ respectively (see appendix).

The table above presents the results found from this research for the six EMCCA countries over the period 2002 to 2020.

At the outset, it should be noted that with regard to the Wald and Fischer statistics and the associated probabilities, all of which are significant, including the $\mathrm{R}^{2}$ of $82 \%$ and $96 \%$ respectively, the model is statistically sound for all estimates. The variables of interest (Corruption, Democracy,) all have significant negative

Table 1. GMM results in Blundell and Bond (1998) system.

\begin{tabular}{|c|c|c|c|}
\hline Variables & Equation $n^{\bullet} 1$ & Equation $n^{\bullet} 2$ & Equation $n^{\bullet} 3$ \\
\hline LPIBt-1 & $\begin{array}{l}1.021224 \\
(0.000) *\end{array}$ & $\begin{array}{c}0.9479 \\
(0.000) *\end{array}$ & $\begin{array}{c}0.9341301 \\
(0.000)^{*}\end{array}$ \\
\hline Corr & $\begin{array}{c}-0.1290262 \\
(0.036)^{\star *}\end{array}$ & $\begin{array}{c}-0.1894338 \\
(0.003)^{\star}\end{array}$ & $\begin{array}{c}-0.623943 \\
(0.134)\end{array}$ \\
\hline Demo & - & $\begin{array}{c}-0.0484829 \\
(0.01)^{\star}\end{array}$ & $\begin{array}{c}0.6326532 \\
(0.682)\end{array}$ \\
\hline Demo $^{*}$ corr. Interaction & - & - & $\begin{array}{c}0.0769878 \\
(0.289)\end{array}$ \\
\hline FDI & $\begin{array}{c}-0.0007094 \\
(0.659)\end{array}$ & $\begin{array}{c}-0.0006181 \\
(0.690)\end{array}$ & $\begin{array}{l}-0.0007285 \\
(0.0015868)\end{array}$ \\
\hline LDP & $\begin{array}{c}-0.2260388 \\
(0.000)^{\star}\end{array}$ & $\begin{array}{c}-0.0793639 \\
(0.268)\end{array}$ & $\begin{array}{c}-0.574149 \\
(0.451)\end{array}$ \\
\hline LFBCF & $\begin{array}{c}0.1684839 \\
(0.000)^{\star}\end{array}$ & $\begin{array}{c}0.1221407 \\
(0.000)^{\star}\end{array}$ & $\begin{array}{c}0.1126598 \\
(0.002)^{\star}\end{array}$ \\
\hline LPop & $\begin{array}{c}0.0768421 \\
(0.021)^{\star \star}\end{array}$ & $\begin{array}{l}0.03448 \\
(0.303)\end{array}$ & $\begin{array}{c}0.067415 \\
(0.875)\end{array}$ \\
\hline Observations & 81 & 82 & 83 \\
\hline $\mathrm{R}^{2}$ & 0.82 & 0.82 & 0.96 \\
\hline Fisher statistics & $\begin{array}{c}77.85 \\
(0.0000)^{\star}\end{array}$ & $\begin{array}{c}63.85 \\
(0.0000)^{*}\end{array}$ & $\begin{array}{c}305.42 \\
(0.000)^{\star}\end{array}$ \\
\hline Stat Wald & $\begin{array}{c}6.25 \mathrm{e}+06 \\
(0.000)\end{array}$ & $\begin{array}{c}77.85 \\
(0.000)\end{array}$ & $\begin{array}{c}5.97 e+06 \\
(0.000)\end{array}$ \\
\hline Sargan test & $\begin{array}{c}97.399 \\
(0.0421)^{\star *}\end{array}$ & $\begin{array}{c}95.435 \\
(0.0402)^{* *}\end{array}$ & $\begin{array}{c}90.12 \\
(0.0847)^{* * *}\end{array}$ \\
\hline
\end{tabular}

Source: authors, based on results obtained on STATA 12 . $^{*},{ }^{*}$ and ${ }^{* *}$ represent the $1 \%, 5 \%$ and $10 \%$ probability thresholds, respectively. The variables in parentheses are the probabilities. 
coefficients at the $1 \%$ and $5 \%$ thresholds respectively, except for the interaction variable (Demo/corr. interaction). Given the good statistical quality of these results, an interpretation is possible. Two major lessons emerge from these results: first, corruption is an obstacle to economic growth in EMCCA countries. Second, taking democracy into account reduces the negative impact of corruption on economic growth.

\section{- Corruption, an obstacle to economic growth in CEMAC countries}

The corruption variable on the first two equations in Table 1 displays negative and significant coefficients, suggesting that a one-point decline in the level of corruption in EMCCA, reduces economic growth. These results put into perspective those of Mauro (1995); Mo (2001); Baliamoune-Lutz, Ndikumana (2009) who showed that corruption hinders growth and corroborates the hypothesis of Otusanya (2011), who conclude that corruption is a hindrance to the economies of developing countries. In the EMCCA context, these results contradict those obtained by Ondo (2017) and there is a possible explanation for this finding. Negative public spending is less profitable for the corruption market. The large budgets voted by EMCCA countries are in reality structurally congruent portions from which a multitude of public managers, often corrupt, must distribute themselves. However, the management of these funds often leads to misappropriation of funds and the financing of unproductive expenditures (white elephants) that should have been used to produce goods and services essential for economic growth. To this can be added the deviant behavior of tax officials who grant derogatory tax regimes. This results in the loss of public resources (Aidt et al., 2008). All other things being equal, this has a negative impact on economic growth.

\section{- Addressing democracy reduces the impact of corruption on economic growth}

The result of the equation capturing the influence of democracy in the corruption-growth relationship shows a positive but insignificant interactive coefficient, and the coefficients associated with corruption and democracy lose their significance. This means that the corruption and democracy variables have undergone the substitution effect. However, this result reinforces the scientific intuition behind this work that democracy reduces corruption and stimulates growth in EMCCA (Cooper Drury et al., 2006). This result, which is close to the one expected, admits of an explanation. The low level of democracy in EMCCA countries. However, this democratic deficit opens the door to corruption that hinders growth. Corruption is generally observed in societies in transition to real democracy, as in the EMCCA countries. The institutional balance has not yet been achieved, and some people abuse the considerable power delegated to them by creating a number of alterations that proliferate corruption (Aidt et al., 2008).

Corruption in EMCCA remains a reflection of governance failure and a mark of a lack of capacity to manage society through balanced systems of social, judicial, political, and economic checks and balances that constitute real democracy, 
which EMCCA needs to better mitigate the effects of corruption on economic growth.

\section{Conclusion}

The objective of this study was to analyze the influence of democracy on the corruption-economic growth relationship in the six EMCCA countries for the period 2002-2020. To do so, we used the Blundell and Bond (1998) method of generalized moments in a system. The results obtained confirm the negative effect of corruption on growth in EMCCA. Moreover, taking into account the interactive influence of democracy in the corruption-growth relationship revealed that the promotion of democratic norms could mitigate the negative effects of corruption on economic growth. This confirms our initial hypothesis (the grain of sand in the wheels).

These results allow us to formulate some policy implications:

- Organize recurrent awareness campaigns aimed at informing all segments of society about what is real corruption in its various forms of observation or manifestation.

- Initiating or adopting an anti-corruption education course in the national education programs of all EMCCA member countries from secondary school onwards would be an asset, in order to inculcate all anti-corruption values in young people.

\section{Limitations of the Study}

Qauh (1996) has noted that the results of GMM model estimations, obtained from panel data, are very sensitive to the estimation methods. The consequence is that there could be measurement biases due to heterogeneity phenomena that are otherwise unobservable. The use of a more sophisticated model is useful to capture heterogeneous effects between countries (legislation, legal rules, etc.) and to take into account aspects of non-linearity. In this perspective, it would also be desirable that the study of the role of democracy on corruption and economic growth be conducted in each EMCCA country in order to capture the specificities of each country. These possible specificities could constitute a signal for political actors in the sub-region.

As another limitation, we can note the limitation of the study period, perhaps a wider period could give other results, i.e. slightly different from those presented in this paper.

\section{Conflicts of Interest}

The authors declare no conflicts of interest regarding the publication of this paper.

\section{References}

Aidt, T., Dutta, J., \& Sena, V. (2008). Governance Regimes, Corruption and Growth: Theory 
and Evidence. Journal of Comparative Economics, 36, 195-220.

https://doi.org/10.1016/j.jce.2007.11.004

Amira, Z. (2014). Corruption's and Democracy's Effects on Economic Growth. https://mpra.ub.uni-muenchen.de/54535/

Arellano, M., \& Bond, S. (1998). Dynamic Panel Data Estimation Using DPD98 for Gauss: A Guide for Users. Review of Economic Studies, 58, 277-297. https://doi.org/10.2307/2297968

Arellano, M., \& Bover, O. (1995). Another Look at the Instrumental Variable Estimation of Error-Components Models. Journal of Econometrics, 68, 29-51. https://doi.org/10.1016/0304-4076(94)01642-D

Baliamoune-Lutz, M., \& Ndikumana, L. (2009). Corruption and Growth: Exploring the Investment Channel. University of Massachusetts-Amherst, Department of Economics.

Bardhan, P. (1997). Corruption and Development: A Review of Issues. Journal of Economic Literature, No. 35, 1320-1346.

Barro, R. (1990). Government Spending in a Simple Model of Endogenous Growth. Journal of Political Economy, 98, S103-S125. https://doi.org/10.1086/261726

Beck, P. J., \& Maher, M. W. (1986). A Comparison of Bribery and Bidding in Thin Markets. Economic Letters, 20, 1-5. https://doi.org/10.1016/0165-1765(86)90068-6

Blundell, R., \& Bond, S. (1998). Initial Conditions and Moment Restrictions in Dynamic Panel Data Models. Journal of Econometrics, 87, 115-143. https://doi.org/10.1016/S0304-4076(98)00009-8

Cooper Drury, A., Krieckhaus, J., \& Lusztig, M. (2006). Corruption, Democracy, and Economic Growth. International Political Science Review, 27, 121-136. https://doi.org/10.1177\%2F0192512106061423

Freedom House (2020). A Leaderless Struggle for Democracy. https://freedomhouse.org/report/freedom-world/2020/leaderless-struggle-democracy

Ghulam, S. (2017). Corruption, Democracy and Economic Growth: Does Conditionality Matter? Pakistan Economic and Social Review, 55, 99-117.

Holtz-Eakin, D., Newey, W., \& Rosen, H. (1990). Estimating Vector Autoregressions with Panel Data. Econometrica, 56, 1371-1395. https://doi.org/10.2307/1913103

Huntington, S. P. (1968). Political Order in Changing Societies (p. 448). Yale University Press.

International Monetary Fund (IMF). (2021). World Economic Outlook: Managing Divergent Recoveries. Washington, DC.

https://www.imf.org/en/Publications/WEO/Issues/2021/03/23/world-economic-outloo k-april-2021

Kaufman, D., \& Wei, S.-J. (2000). Does 'Grease Money' Speed up the Wheels of Commerce? Working Paper WP/00/64, International Monetary Fund. https://doi.org/10.5089/9781451848557.001

Kaufmann, D., \& Wei, S.-J. (1999). Does “Grease Money” Speed Up the Wheels of Commerce? Working Paper No. w7093, National Bureau of Economic Research (NBER). https://doi.org/10.3386/w7093

Kaufmann, D., Kraay, A., \& Mastruzzi, M. (2010). The Worldwide Governance Indicators: Methodology and Analytical Issues. Working Paper No. 5430, World Bank Policy Research.

Kurer, O. (1993). Clientelism, Corruption and the Allocation of Resources. Public Choice, 
77, 259-273. https://doi.org/10.1007/BF01047869

LaFree, G. \& Morris. N. (2004). Corruption as a Global Social Problem. In G. Ritzer \& T. Oaks (Eds.), Handbook of Social Problems: A Comparative International Perspective (pp. 600-618). Sage Publications. https://doi.org/10.4135/9781412973526.n34

Leff, N. H. (1964). Economic Development through Bureaucratic Corruption. The American Behavioral Scientist, 8, 8-14. https://doi.org/10.1177\%2F000276426400800303

Leys, C. (1965). What Is the Problem about Corruption? Journal of Modern African Studies, 3, 215-230. https://doi.org/10.1017/S0022278X00023636

Lucas, R. E. (1988) On the Mechanics of Economic Development. Journal of Monetary Economics, 22, 3-42. https://doi.org/10.1016/0304-3932(88)90168-7

Mauro, P. (1995). Corruption and Growth. The Quarterly Journal of Economics, 110, 681-712. https://doi.org/10.2307/2946696

Mauro, P. (1998). Corruption and the Composition of Government Expenditure. Journal of Public Economics, 69, 263-279. https://doi.org/10.1016/S0047-2727(98)00025-5

Méon, P.-G., \& Sekkat, K. (2005). Does Corruption Grease or Sand the Wheels of Growth? Public Choice, 122, 69-97. https://doi.org/10.1007/s11127-005-3988-0

Mo, P. H. (2001). Corruption and Economic Growth. Journal of Comparative Economics, 29, 66-79. https://doi.org/10.1006/jcec.2000.1703

North, D. (1990). Institutions, Institutional Change, and Economic Performance. Cambridge University Press. https://doi.org/10.1017/CBO9780511808678

Ondo, A. (2017). Corruption and Economic growth: the case of CEMAC. Theoritical Economics Letters, 7, 1292-1305. https://doi.org/10.4236/tel.2017.75088

Otusanya, O. J. (2011). Corruption as an Obstacle to Development in Developing Countries: A Review of Literature. Journal of Money Laundering Control, 14, 387-422. https://doi.org/10.1108/13685201111173857

Przeworski, A., \& Limongi, F. (1993). Political Regimes and Economic Growth. Journal of Economic Perspectives, 7, 51-69. https://doi.org/10.1257/jep.7.3.51

Qauh, D. T. (1996). Empirics for Economic Growth and Convergence. European Economic Review, 40, 1353-1375. https://doi.org/10.1016/0014-2921(95)00051-8

Rose-Ackerman, R. (1997). The Political Economy of Corruption. In D. K. A. Elliott (Ed.), Corruption and the Global Economy (pp. 31-60). Institute for International Economics.

Saha, S., Gounder, R., \& Campbell, N. (2014). Democracy and Corruption: A Complex Relationship. Crime, Law and Social Change, 61, 287-308. https://doi.org/10.1007/s10611-013-9506-2

Schleifer, A., \& Vishny, R. W. (1993). Corruption. The Quarterly Journal of Economics, 108, 599-617. https://doi.org/10.2307/2118402

Seka, (2013). Corruption, Growth and Human Capital: What Relationships? Africa and Development, 38, 133-150.

Shera, A., Dosti, B., \& Grabova, P. (2014). Corruption Impact on Economic Grouwth: An Empirical Analysis. Journal of Economic Development, Management, It, Finance and Marketing, 6, 57-77.

Solow, R. M. (1956). A Contribution to the Theory of Economic Growth. The Quarterly Journal of Economics, 70, 65-94. https://doi.org/10.2307/1884513

Tanzi, V., \& Davoodi, H. R. (2002). Corruption, Public Investment, and Growth. In G. T. Abed, \& S. Gupta (Eds.), Governance, Corruption, and Economic Performance (pp. 
280-299).

United Nations (2021). World Economic Situation and Prospects as of Mid-2021. Department of Economic and Social Affairs, United Nations. https://www.un.org/

Wittman, D. (1989). Why Democracies Produce Efficient Results? Journal of Political Economy, 97, 1395-1424. https://doi.org/10.1086/261660

World Development Indicators (WDI) (2020). DataBank.

https://databank.worldbank.org/source/world-development-indicators 


\section{Appendix}

Table A1. Unit root test results (LLC and IPS)

\begin{tabular}{ccccccc}
\hline Series & \multicolumn{2}{c}{ LLC } & P value & $\begin{array}{c}\text { Trend, } \\
\text { intercept, } \\
\text { none }\end{array}$ & Z & P value \\
\cline { 2 - 7 } & $\begin{array}{c}\text { Trend, } \\
\text { ntercept, } \\
\text { none }\end{array}$ & $\mathbf{Z}$ & IPS & \\
\hline LPIB $^{*}$ & Trend & -6.07585 & 0.0000 & Trend & -2.61087 & 0.0045 \\
CC $^{* *}$ & None & -6.63983 & 0.0000 & Trend & -2.64559 & 0.0041 \\
Demo $^{* *}$ & Trend & -2.62775 & 0.0043 & Intercept & -4.09203 & 0.0000 \\
LFBCF $^{* *}$ & Trend & -2.72669 & 0.0032 & Trend & -5.43462 & 0.0000 \\
LD-pub $^{* *}$ & None & -3.10181 & 0.0010 & Trend & -4.13822 & 0.0000 \\
LPopu $^{*}$ & Trend & -7.61599 & 0.0000 & Trend & -6.03934 & 0.0000 \\
IDEA $^{*}$ & Trend & -3.51530 & 0.0002 & Trend & -2.84124 & 0.0022 \\
\hline
\end{tabular}

Source: authors, $\left({ }^{*}\right)$ and $\left(^{* *}\right)$ mean respectively stationary variables in level, stationary variables in first difference.

The results of the LLC (2002) and IPS (2003) tests applied to the series in level and first difference show that the series are all stationary at the $1 \%$ threshold.

Table A2. Results of pedroni cointegration test.

\begin{tabular}{|c|c|c|c|c|}
\hline \multicolumn{5}{|c|}{ Alternative hypothesis: common Ar coefs: (Within-dimension) } \\
\hline Test statistics & V-stat & Rho-stat & Pp-stat & ADF-stat \\
\hline Value & -2.174761 & 2.19467 & -0.482897 & 2.790986 \\
\hline P-value & 0.9852 & 0.9860 & 0.3146 & 0.9974 \\
\hline \multicolumn{5}{|c|}{ Alternative hypothesis: Individual AR coef (between dimension) } \\
\hline Test statistics & Group Rho-stat & Group pp-stat & \multicolumn{2}{|c|}{ Group ADF stat } \\
\hline Value & 3.238603 & -5.117002 & \multicolumn{2}{|c|}{-2.664136} \\
\hline P-value & 0.9994 & 0.0000 & \multicolumn{2}{|c|}{0.0039} \\
\hline
\end{tabular}

Source: authors from eviews 7 software. Trend assumption: NO deterministic trend, Series: CC, Demo, LPib, LOuv, LIdeen, Lnpopulation

The results of the Pedroni cointegration tests presented below reveal at least one cointegrating relationship out of the 7 equations that constitute the Pedroni test. In conclusion, we accept the alternative hypothesis of the existence of a cointegration relationship in the medium and long term between economic growth and its determinants, namely corruption, democracy and the other control variables at the $1 \%$ threshold. 